\title{
What future for social housing in England?
}

\author{
Ian Cole* \\ Sheffield Hallam University
}

\begin{abstract}
This article summarises some of the different perspectives that have been brought to bear in recent academic and policy debate about the future of social housing in Britain. It identifies four main approaches, described as 'market idealist', revisionist', 'preservationist' and 'reformist'. It puts forward a critical assessment of each perspective on both normative and empirical grounds. The paper then considers the recent 'Hills report' on the future of social housing in England and Wales, developed from a reformist standpoint. In conclusion, the paper asks whether the analytical merits of the Hills report will provoke a considered policy response, which moves away from the narrow and rigid thinking about the social housing sector that has predominated over the past two or three decades.
\end{abstract}

Keywords: social housing; policy development; housing tenure; state and market.

\section{Introduction}

5 July 2008 will be commemorated as the sixtieth anniversary of the National Health Service - the still great, if slightly battered, British institution founded by the post-war Labour government, and launched in a Manchester hospital photocall ${ }^{1}$ by Aneurin Bevan on the anointed day. It is doubtful whether similar fanfares will mark the sixtieth anniversary the following year of another of Bevan's achievements - the passing of the 1949 Housing Act. This legislation (in addition to introducing improvement grants for poor quality private sector dwellings) removed the statutory restriction that limited public housing to the 'working classes' - a symbolic gesture that gave legislative embodiment to Bevan's vision of a truly universal sector expressed by his now familiar phrase of capturing 'the living tapestry' of a mixed community. In practice, of course, Bevan's vision turned out to be the briefest of glimpses and council housing never gained the foothold in the British welfare state that state health and education occupied then, and continue to occupy in the present century.

In this sixty year period council housing (or, latterly, 'social' housing) has been 'at the crossroads' more times than even the most energetic of Manhattan tourists. The sector has been riddled with legislation, labyrinthine financial arrangements, countless subsidy regimes, perennial debates about its cost, its management performance, the design and quality of its dwellings and the impact of the sector on the tenants who live 
in it. And last year another inquisition into its purpose was launched. After a relatively quiescent period, the Secretary of State for Communities, Ruth Kelly, announced within weeks of her appointment that a fundamental review of the future role of social housing was to be undertaken, led by Professor John Hills. The Hills review has now been published (Hills, 2007) and so it is perhaps opportune to set this assessment against other recent prognostications about the future of the sector - sometimes backed up by research and analysis, sometimes not.

This brief paper will not attempt to summarise the intervening period between Bevan and Hills - there is a wealth of sources on the process whereby the social housing sector expanded and then contracted, becoming increasingly fragmented, residualised and commodified (Malpass, 2005, Mullins et al, 2006, and Lund, 2006). From the mid 1970s, the proportion of social housing in the housing market in England declined, and the sector is now just slightly bigger as a proportion of the housing market than it was at the end of the 1945-51 Atlee government - accounting for 19 percent of the stock now (for housing association and council dwellings combined), compared to 17 percent (nearly all in the local authority sector) in 1951.

Increasingly the housing formerly reserved for the 'working classes' has become the sector for the 'non working classes' - with only 32 per cent of all tenants in any kind of employment (34 per cent of those of working age are in full-time employment and a further 15 per cent in part-time employment). Bevan's view that the council estate of the future would give tangible expression to his commitment to mixed communities has given way to the present government's enthusiasm for mixed communities premised on the dilution rather than expansion of social housing in some poorer neighbourhoods across the country (DCLG, 2006). And Bevan's 'living tapestry' has become, for some analysts, a comfort blanket, suffocating those who still insist on clinging to it.

Hills' review has been undertaken against a backdrop of different normative and analytical perspectives towards the recent development and future role of social housing. This paper seeks to situate these interpretations of the actual and potential role of social housing in England's housing market, and to examine briefly the policy prescriptions which flow from them. Hills' report will then be assessed against these contributions in order to consider how the shape of housing policy and public intervention is likely to change in the years ahead.

\section{The 'market idealist' perspective}

The commentators described as 'market idealists' are basically antagonistic to the ideas, principles and practice of social housing. This perspective has been less prominent since the retreat of Thatcherism. Its high point in terms of policy influence was probably the succinct 1987 White Paper Housing (HMSO, 1987), which confidently sounded the death knell of public rented housing (only to witness a collapse in much of the owner-occupied market two to three years later). There are now signs of renewed vigour amongst these opponents to social housing, possibly sensing the end of an era and grasping this opportunity to press their case anew.

This position has received a recent airing by Peter King (King, 2006), a prolific writer on issues about housing, philosophy and the welfare state and here romping around in robust polemical mode. The very title of his book, 'Choice and the End of Social Housing' (published by the free market think tank, the Institute of Economic Affairs (IEA)) perhaps conveys the sense in which this is not a tome for the ambivalent, the sceptical or the cautious. Indeed King crashes his way through the thicket of policies, initiatives and measures towards social housing introduced in the past sixteen years or 
so, since Thatcher left the scene. True to the 1950s heyday of IEA pamphlets, when Richard Titmuss and fellow Fabians were assaulted at every turn, King denounces current 'housing policy' for being too centralised, feeding 'producer capture', thwarting genuine choice, bamboozling policy debate with empty jargon, wasting money on illtargeted subsidies and reinforcing stigma. Some of the incidental sparring hits home his critique of the current enthusiasm for the rather flaky notion of 'sustainable communities', for example, but there are fundamental difficulties at the core of his central argument for future reform.

King proposes the end of any special privileges for social landlords by removing subsidies, tax concessions and tax privileges so there is a 'level playing field' for all landlords. The current need for tenant ballots to approve a change of landlord from local authorities to housing associations would be abolished. Instead all landlords (whether 'social' or 'private') would have the freedom to use their assets as they see fit. Tenants would thus be given 'genuine choice' to take their custom wherever rather than taking part in a one-off ballot: a prime example of the market taking precedence over the vote.

One of the most beguiling contrasts one often discerns in writers from a 'free market' position such as King is the stern hand they take to the 'public sector' compared to the insouciance with which the operation of the 'market' is treated. A quick glance at the housing system in England would reveal a complex intertwining between the state and the private sector - not just in obvious realms such as joint partnerships, but in land ownership and control, subsidies (such as Social Housing Grant for developers), 'affordable' housing provision, equity loans, borrowing powers, landlord accreditation schemes, and above all in directing macro-economic policy to maintain a low interest rate regime at its heart. To typify this relationship as one in which 'the market' is constantly choked by the state stretches credulity. An empirical analysis of these issues would show that the relationship tends to be multi-layered, often contradictory and suggestive of mutual dependence as much as mutual antagonism.

Nevertheless, for King, in this relationship, the 'private sector' simply needs to be left unfettered by the ever controlling state. Any lingering concerns that housing does not fit the bill as a 'market commodity', indistinguishable from, say, sugar - or indeed bricks - are cast aside. The notions of housing as a merit good, or as an asset with negative and positive externalities, or that limitations on necessarily finite ingredients such as developable land in a crowded country like England will constrain supply, or that the geographically fixed nature of housing builds in, at the very least, some inflexibilities - such concerns are ignored. However, at least King briefly considers why social housing is different from other public services, such as health or education, so that the state may maintain a legitimate interest in the latter areas, while dispensing with its role in housing. He dispenses rapidly with some propositions - that housing is essential to our quality of life, or that shelter is a fundamental human need for which at least some minimal public provision should be made. Instead, he settles on 'information asymmetry' as the key point of difference for housing compared to health or education. Given the centrality of the notion to his case, it merits some further explication.

If we have a stomach pain we can not operate effectively as free consumers choosing our doctors in the market place - because we do not know enough to know whether this is a bit of indigestion, or a perforated appendix. We need professional expertise as an intermediary between our need and the alternative suppliers of relief to our pain. No such advice is needed, argues King, in choosing our housing: we know what we like and there is no need for professionals to decipher on our behalf what is being offered. In this blissful artifice of the perfect market, we are not mis-sold 
endowment mortgages - we simply did not acquire sufficient information about the future direction of stocks and shares over the next 25 years when we took them out; we did not need a professional surveyor to reveal dry rot in the kitchen floorboards we just took a punt on the essential gamble that is the essence of market exchange. And if the poor end up congregated together in the worst quality property in the least popular neighbourhoods - a few vouchers will rid them of this stigma and a dose of budget management and enable them to operate as faux consumers in the parallel world of the 'welfare benefit' market place. This approach is, King suggests, a genuine attempt to 'put people first'. In response, one might suggest that it just happens to put the rich at the front and cast the poor and vulnerable adrift in the process, as a trip across the Atlantic to, say, Detroit or Baltimore might confirm.

\section{The 'revisionist' perspective}

If the market-centred perspective of King has an unerring consistency in its treatment of social housing, a second (and related) position is taken up by writers who think that social housing once did have a place in the housing system, but things have now moved on and it is time to wave goodbye. This group, who once believed and now do not, might be termed the 'revisionists' in the debate about social housing. Their viewpoint is crystallised in the Smith Institute report of 2006, 'Rethinking Social Housing' (Dwelly and Cowans, 2006). This offers a critique of what is termed the 'welfarist' assumptions of social housing. The two editors present the case in extremis; other contributions (such as those by Rouse and Williams) tend to focus on particular elements of the housing system and are more measured in their claims.

The editors claim that social housing is, in that tired phrase, the 'tenure of last resort', which is 'stigmatised and reviled' (op cit, p. 4). Passing lightly over quite complicated evidence about the existence of 'neighbourhood effects' (Musterd et al, 2003; Atkinson and Kintrea 2002), Dwelly claims that all indicators of poverty are magnified by housing poor people together. Social housing, in another well-worn epithet, is 'part of the problem, not the solution' (op cit p. 8). There is no place for this old brand in the digital world of the twenty first century. The role of any public service should be to give a 'hand up, not a hand out' and (with cliché overload imminent) to 'help them [tenants] help themselves'.

The emphasis is on removing barriers to opportunity that lock people into council estate dependency. Entrants into the social housing system are dealing with a short term emergency but are given, in response, a long term asset - a secure home for life. While there may have been a case for such a safety net in periods of mass unemployment, they argue, this no longer holds true and no one needs social housing when jobs are everywhere. The role of social housing is as a short term expedient - an 'ambulance service for the poor' as Michael Harloe described it thirty years ago except that Harloe intended the phrase to serve as a warning rather than an accolade.

The revisionists claim that the growth in employment over the past fifteen years has passed many social housing tenants by, creating a system of welfare dependency for their children who then become adept at getting accepted as homeless as they perpetuate a cycle of pampered disadvantage. The social housing sector conspires in this process, by treating 'need' and vulnerability as prized attributes, rather than reward and effort (op cit p. 19). As demand for social housing tends to outstrip supply, some will inevitably be left out. For those already in permanent tenancies, however, they can remain insulated from any housing market or labour market pressures, cosseted as they are by housing benefit to meet the bills. 
The editorial style of Rethinking Social Housing is definitively demotic New Labour. Short sentences. Sweeping assertions. Shibboleths discarded. Brave new worlds ushered in. The only sound is that of new brooms sweeping dead thinking away. The only inconvenient thing is that much of this analysis is lazy, many of the underlying assumptions are threadbare and the policy prognosis often seems facile.

A response to the revisionist perspective might point out that:

- increased demand for social housing is not necessarily a symbol of its failure to 'keep pace', any more than the success of right to buy was due to the failure of council housing - if it was such a poor product, tenants would not have bought into it so enthusiastically, even at discount. The demand is an indication of pressures elsewhere (poor standards, overheating local markets, lack of access for those seeking to enter home ownership, and so on) as well as important improvements in the quality of the product on offer, not least due to the additional investment through the 'decent homes' programme, one of New Labour's least heralded achievements. ${ }^{2}$

- the impact of neighbourhood in compounding a dependency culture is easier to assert as 'common sense' than to demonstrate through research. There is in fact some counter-intuitive evidence that mixed communities provoke greater residential dissatisfaction by bringing the 'affluent' and the 'poor' closer together - rich neighbours may be the focus of scorn rather than wholesome role models for the poor to spend the rest of their lives trying to emulate (Cheshire, 2007).

- social housing has always been a variable product, dealing with quite different market contexts, and with considerable variability in the quality and condition of stock, rates of turnover, management performance and so on. It does not fit sweeping assertions well. This diversity of role and function in local housing markets has itself been stretched further as a result of growing market differentiation at regional, sub-regional and local levels (Hickman and Robinson, 2006). The role of social housing, the profile of tenants, the nature of waiting lists, the average length of tenancy - all these are likely to be sharply different in central London, for example, than in Loughbrough or Lancaster. To assume a unitary cause-effect relationship at play across the country is implausible, given the extent of local variability.

- revisionists tend to lapse into tenure determinism and accord tenure a role in shaping outcomes and lifestyles that it does not merit. 'Council dependency' is thus the mirror image of the 'ontological security' of home ownership - but this latter quality was rather shaken when the housing market collapsed in the late 1980s. To assume that certain tenures carry eternal features that shape their residents is bold indeed, and very difficult to substantiate.

- the assumption that 'housing need' tends to be transient, readily shaken off when one has pulled oneself together, is also open to challenge. Many needs are complex, dynamic and long standing and the role of social housing as a 'refuge' from some of the harsher economic and social processes at play should not be discarded lightly in favour of a view that social housing is an impediment to social and economic mobility and little else. Social housing is becoming an increasingly important sector, for example, for members of minority ethnic communities facing overcrowding and affordability problems in owneroccupation, or poor standards of management and stock condition in the low value end of the private rented market. 


\section{The 'preservationist' perspective}

The basic principles behind this approach can be summarised more concisely than other perspectives. The preservationists are, in fact, as much concerned with the internal composition of the social housing sector as its overall role in the housing system. The central objective is to defend council housing against its transfer to housing associations or arms length management organisations and to press for what is called the 'fourth option' - direct public investment in local authority housing. The 'preservationists' have opposed from the outset the government's intention, reiterated in the 2000 Housing Green Paper, to aim for a target of transferring 200,000 dwellings per year out of the local authority sector (for a collection of papers developing the case against stock transfer, see Defend Council Housing. 2006).

The 'Defend Council Housing' lobby has secured some success at local level in supporting groups of tenants to reject the offer of a transfer to another landlord, a housing association, or an arm-length management organisation. A 'no' vote has its costs, as the local authority will not receive additional government resources for investment in its stock to enable the 'decent home standard' to be achieved. It is then perhaps surprising that in nearly sixty local authorities tenants have voted to reject proposals to transfer the whole council housing stock (ranging from small housing authorities such as Waverley and Fareham to larger landlords such as Brighton, Edinburgh, Stockport and Sedgefield), with about twenty other cases where proposals for partial stock transfer were rejected. Set against this, tenants voted in favour of transfer in 118 local authorities between 1997 and 2006, with a further 38 local authorities included in the transfer programme for $2006 / 7$.

While local circumstances affecting the ballot outcome have varied, key aspects in many campaigns have been the degree to which the new landlord (or management body) has won the 'trust' of tenants and how far concerns about loss of security of tenure have affected the response to transfer proposals. The outcome of some 'no' votes suggests that the government may have misread the resilience of support for council housing, at least on the basis of 'better the devil you know', if not necessarily as positive endorsement of municipal landlordism overall.

For the two largest landlords in Britain, Birmingham and Glasgow, the outcomes of transfer proposals have been indeterminate (for an analysis of the two transfers see, Daly et al, 2005). Glasgow voted 'yes' for transfer in 2002 but a first stage transfer to Glasgow Housing Association, as a holding body pending subsequent devolution to community-based associations across the city - but the process has been delayed and questions have been raised about the capacity of the new bodies. In Birmingham, after a high profile campaign, tenants voted 'no' and revised proposals for more dispersed forms of management in the city are still being developed. There are now an increasing number of local authorities caught in limbo, without the resources to invest in stock improvements but with tenant support to continue as the landlord of choice.

At national level, the campaign has gathered considerable constituency and backbench support in the Labour Party, but the main case - direct investment in local authority landlordism - has not been taken up in government policy, despite close semantic scrutiny of statements by ministers from time to time, which have raised hopes of a change. As the issue has become a totemic indicator of divisions between 'new' and 'old' Labour, and between policymaking by party versus policymaking by Cabinet, it is difficult to imagine any change of policy, whether under Blair or the next prime minister in this term.

The preservationists have been able to point out that the case for transfer, coupled to additional investment, has rarely been subject to close cost-benefit scrutiny. An 
exercise to compare the efficiency of different routes to invest in social housing, undertaken by the then ODPM in 2003, came up with equivocal results, in that the financial costs and benefits varied widely according to the housing market context and the size, value and quality of the stock. The preservationists can also claim with some justification that some key principles (such as the pooled historic cost principle for rent accounting) have been discarded rather too casually as the sector has been reduced (Ambrose, 2006). While research suggests that levels of resident satisfaction and extent of participation have often risen following transfer, it is difficult to control for the influence of the consultation process over transfer and the mollifying impact of additional spending released for tenants' homes. But stock transfers have clearly been promoted by the government for reasons other than relative financial economic gains the whiff of Old Labour is just too strong on those council estates.

However, it is difficult to sustain an argument that council housing is superior in every respect, and in every neighbourhood, than other rented options. Council housing in Britain has had a mixed record since its formation. While its considerable strengths and successes over the past hundred years have rarely received the attention they merited, the record is not unblemished either - on issues such as management practices, neglect of maintenance, short-term rental structures, tenant involvement and local elected member influence, there are myriad cases of councils offering a poor service which cannot be put down solely to lack of resources from central government. The 'lived experience' of council tenants has often fallen far short of what Bevan envisaged - a fact not lost on Margaret Thatcher, among others, in the 1980s.

\section{The 'reformist' perspective}

The final group is the most disparate of the four, but is underpinned by a commitment to re-make social housing, by adapting its role and, alongside that, rethinking the role of the state itself in the housing market, above and beyond a specific tenure. This perspective may be illustrated by the paper prepared by Duncan MacLennan for the Joseph Rowntree Foundation and submitted to the Hills review (Maclennan 2006; see also Maclennan, 2007).

In his paper, which is as discursive conceptually as it is geographically, Maclennan tilts the focus of the debate away from tenure per se, and towards housing organisations, arguing that 'system redesign and local integration' rather than 'new initiatives and resources' should be at the heart of the next phase of change. Maclennan dispenses with assumed cause-effect relationships about concentrations of poverty in the social housing sector, suggesting instead that it is where the "poverty outcomes of other influences' come to rest. He also asserts, in opposition to the revisionist case, that non-market housing can provide decent homes and neighbourhoods, and contrasts this with the 'bleak meanness' of more thoroughgoing market systems in countries such as the United States and Australia. And he eschews a priori, 'in principle' arguments from whatever direction - whether in favour of preserving the social sector untouched or of adopting market solutions wholesale.

Maclennan emphasises the diversity of performance between different housing providers, which is related more to stock size, operational structure and so on rather than tenure itself, as preservationists would suggest. Government inspection does not help much here, as it is focused on individual landlords rather than the adequacy of the housing system at local or district level. Maclennan claims that the current system to monitor service performance is overbearing, inadequately specified and does not stimulate greater productivity in housing management. 
Maclennan argues that stock transfer has helped to drive cultural and service change and garnered staff commitment as well as more positive views from tenants about transfer. However, he notes that this has not prompted innovation in organisational forms for housing services, or any wider restructuring of local provision across organisational boundaries. The paper suggests that housing associations need to adopt more flexible modes of provision, involving low cost home ownership, shared equity and also other aspects of neighbourhood management and community development. It also challenges the widespread view among lenders that smaller is necessarily riskier, and suggests that lenders have an instinctive, rather than empirically informed, attitude towards the relationship between risk, scale and cost.

Given the spatial concentration of social housing, Maclennan argues that it is impossible to remake social housing without remaking places too. But the achievement of wider social outcomes ('housing plus', in its various guises) has often been despite, rather than because of, the regulatory and financial regimes in the sector. Closer convergence between accounting and financial rules and subsidies between the local authority and housing association sector should be accompanied by more flexible interchange in other arenas, so that housing providers need to go across local government boundaries if a more effective service can be delivered as a result.

Maclennan's paper is premised on continuing the mix between market and nonmarket means to reach social objectives which has been an integral feature of British housing policy over the years(as in the payment of housing benefit to private tenants, or in engaging private developers to build housing association dwellings). The overall thrust of the reformist argument is towards restructuring the nature of social housing provision, not according to a pre-conceived template but on the basis of cool-headed analyses of housing market dynamics at different sub-regional and local levels.

\section{Situating the Hills report}

Given this inchoate array of perspectives, indictments, policy sermons and ideologies about the future of social housing, where does the 'Hills report' fit in? There is, as one might expect, a certain difference of tone. John Hills' disciplinary background is economics, like Maclennan, and his analytical inclinations are more forensic than histrionic; his report is founded on careful scrutiny of the evidence about the housing system and the role of social housing within it. Of course, attention to evidence does not permit just one interpretation of what has caused the current shape of social housing and how it might best be changed - but a degree of empiricism is a helpful counterbalance to the airier charges about policy and service failure that have marked some of the other texts considered here. If some of the cultural and status attributes of the housing system (such as stigma, niche markets, and drivers of residential mobility) are perhaps underplayed in the report, it nevertheless offers a solid analytical foundation for the policy messages that subsequently flow from it.

John Hills' report sets out a quintessentially 'reformist' agenda. Concerned only with the future role of social housing as a tenure, Hills is working on a smaller canvas than Maclennan but the diagnosis and prognosis are not dissimilar. His underlying message to social housing providers is 'adapt to survive'. The report is primarily concerned with the impact of social housing on achieving more socially mixed neighbourhoods, fostering labour mobility and improving the prospects for (longer distance) geographical mobility in and around the housing system. Hills sees himself, understandably, as setting a 'direction of travel' rather than making specific recommendations. The core issues are not a comprehensive summation of the 
challenges facing the sector, but this narrower focus at least helps Hills avoid several policy cul-de-sacs or diversions along the way.

The Hills report has received considerable coverage in the national media and the professional press, and the official summary conveys the main findings and key points. It has struggled to meet the 'soundbite test' - easy messages - and is none the worse for that. Rather than attempt to summarise the report here, it is perhaps more appropriate to indicate how some of the underlying principles might be aligned against themes covered earlier in this paper:

- it is vital to recognise local variability in housing markets and the role played by social housing. If the function of social housing is primarily as a market corrective, this market differs sharply from place to place, and social housing will have an especially important function in higher cost, tighter housing markets;

- it is likely that the increasing proportion of elderly home owners will fuel a cascade of housing wealth through the generations, helping first time and lower income buyers to sustain mortgages that would otherwise be beyond their means. This will intensify the exclusion of social housing tenants unless counterbalances are introduced for them;

- a 'freer' housing market can be an impediment to labour mobility, especially at inter-regional level, so social housing can help to lubricate mobility as much as thwart or dampen it;

- a range of measures are necessary, not just large scale remodelling, to promote mixed income neighbourhoods, through selective sales, use of vacant land, higher quality management, and new allocations and access policies;

- 'one tenure' solutions need to be replaced by more calibrated approaches to state/market interactions and a more varied 'offer' to tenants - including more sustained support for 'intermediate' tenures;

- advice and support will be needed to help households navigate through the more varied housing options on offer - this could include part equity purchase or savings through additional rent payments.

The essence of the Hills report is to promote more diverse pathways for lower income households to negotiate ever more complex local housing markets. This is a different scenario to some of the 'one-shot' solutions outlined earlier. But fundamental housing market changes are already unfolding rapidly for many households on low and middle incomes - not least as assumptions about early entry into affordable home ownership recede into the distance and disappear over the horizon. Hills' criticisms of the rigidities of the British housing system are not new - but his report has been published at a time when these rigidities are starting to bite, for a cluster of economic, social and demographic reasons.

\section{Conclusion}

It is always tempting to invoke the ghost of erstwhile pioneers to bless new departures in policies and priorities - they cannot answer back. So one needs to tread very carefully indeed in wondering what Aneurin Bevan would have made of these debates about the future role of social housing. The reformist case for what Maclennan terms a 'multi-instrument' strategy for low income households, rather than a focus on the size of any single housing sector, might open the door for more sophisticated forms of public intervention and control. ${ }^{3}$ They might in turn accord with the public mood and emerging housing priorities, especially if the financial pressures on owner-occupation and concerns about the 'new' private rented sector continue to mount. The state's role 
in the housing market - not confined to 'social housing' - might even become more popular as a result. ${ }^{4}$ A tipping of the scales towards social justice goals rather than economic efficiency and, who knows, the suggestions by John Hills and Maclennan might even have received Bevan's support.

But it is impossible to extend such musings without reference to the realities of the current political climate. Sixty years ago, Bevan was pressing the case for a universal service in health, education and housing in a post-war government with a unique singularity of purpose. Whether some of the more modest ideas for social housing reform raised in this paper will gain a hearing among current ministers, and whether they will then garner a wider groundswell of political support in any post-Blair administration, remains a much tougher call to make.

\section{Notes}

1 It was the hospital at the end of the road where I lived as a child - called 'Park Hospital' in those pre-corporate days: now renamed as...Trafford General.

2 The relative success of the decent homes programme in the public sector, compared to the limited impact in the private sector, reveals a further advantage to governments. Social housing can be used more readily as a lever to secure other policy objectives as in the case of the anti-social behaviour/'respect' measures introduced in recent years.

3 One might wonder whether some of the original thinking behind Housing Market Renewal Pathfinders was edging in this direction, before it became 'normalised' as a more conventional housing and regeneration programme. This is, however, a topic for another occasion.

${ }^{4}$ And, to pro-market advocates, that was the biggest problem of Bevan's legacy - for a period of time public housing was undeniably popular.

* Correspondence Address: lan Cole, Centre for Regional Economic and Social Research, Sheffield Hallam University, Unit 10, Science Park, Howard Street, S1 1WB, UK. Email: i.d.cole@shu.ac.uk.

\section{References}

Ambrose, P. (2006) What is the Housing Problem?, in: Defend Council Housing The Case for Council Housing in 21st Century Britain. Nottingham: Russell Press.

Atkinson, R. and Kintrea, K. (2002) Area effects: what do they mean for British housing and regeneration policy? European Journal of Housing Policy, 2, 2, 147-166.

Cheshire, P. (2007) Urban Economic Dynamics, Helping Places and Mixing Communities: A Critical Analysis. London: Joseph Rowntree Foundation London School of Economics.

Cole, I. and Furbey, R. (1993) The Eclipse of Council Housing. London: Routledge.

Daly, G, Mooney, G, Poole L and Davis H (2005) 'Housing Stock Transfer in Birmingham and Glasgow: the Contrasting Experiences of Two UK Cities' European Journal of Housing Policy, 5, 3, 327-341.

Defend Council Housing (2006) The Case for Council Housing in $21^{\text {st }}$ Century Britain. Nottingham: Russell Press. 
Department of Communities and Local Government (DCLG) (2006) From Decent Homes to Sustainable Communities: A Discussion Paper. London: DCLG.

Dwelly, T. (2006) 'Social Housing Isn't Working' in Dwelly and Cowans (eds) (2006) Rethinking Social Housing. London: Smith Institute.

Dwelly, T. and Cowans, J. (eds) (2006) Rethinking Social Housing. London: Smith Institute.

Hickman, P. and Robinson, D. (2006) 'Transforming Social Housing: Taking Stock of New Complexities' Housing Studies, 21, 2, 157- 170.

Hills, J. (2007) Ends and Means: The Future Roles of Social Housing in England CASE report 34. London: London School of Economics.

HMSO (1987) Housing: The Government's proposals Cmd 214. London: HMSO.

King, P. (2006) Choice and The End of Social Housing Institute of Economic Affairs Hobart Paper 155. London: IEA.

Lund, B. (2006) Understanding Housing Policy. Bristol: Policy Press.

Malpass, P. (2005) Housing and the Welfare State. London: Palgrave Macmillan.

Maclennan, D. (2006) 'Looking Forward, Aiming Higher? Paper to the Joseph Rowntree Foundation Housing and Neighbourhoods Committee. York: JRF.

Maclennan, D. (2007) 'Housing Connections' in Search Issue 45 February. York: JRF.

Mullins, D., Murie, A. Leather, P. and Lee, P. (2006) Housing Policy in the UK. London: Palgrave Macmillan.

Musterd, S., Ostendorf, W. and de vos, S. (2003) 'Neighbourhood Effects and Social Mobility' Housing Studies, 18, 6, 371-380.

Rouse, J. (2006) 'New Affordable Housing - Time to Embrace a Truly Mixed Economy' in Dwelly and Cowans (eds) (2006) Rethinking Social Housing. London: Smith Institute.

Williams, P. (2006) 'How Can High Street Lenders Help Extend Home Ownership?' in Dwelly and Cowans (eds) (2006) Rethinking Social Housing. London: Smith Institute. 